\title{
Does switching from NASDAQ to the NYSE affect investment-cash flow sensitivity?
}

\author{
Chau-Chen Yang ${ }^{a}$, H. Kent Baker ${ }^{b, *, 1}$, Li-Chuan Chou ${ }^{c}$, Bo-Wei Lu ${ }^{\text {a }}$ \\ a National Taiwan University, College of Management, Department of Finance, Roosevelt Road, Taipei 106, Taiwan, ROC \\ ${ }^{\mathrm{b}}$ American University, Kogod School of Business, Department of Finance and Real Estate, 4400 Massachusetts Avenue, NW, Washington, DC 20016, United States

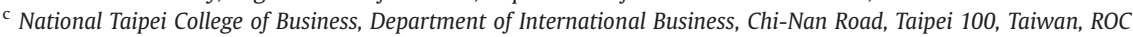

\section{A R T I C L E I N F O}

\section{Article history:}

Accepted 23 May 2008

Available online $\mathrm{xxxx}$

\section{JEL classification:}

G10

G14

\section{Keywords:}

Cash flow sensitivity

Exchange switching

\begin{abstract}
A B S T R A C T
We examine whether a firm's sensitivity of investments to cash flow changes when it switches from the NASDAQ to the NYSE over the period 1992-2002. Contrary views exist on the effect of listing switches on investment sensitivity to cash flow. Investment-cash flow sensitivity is a proxy for the degree of uncertainty of using internal funds to finance a firm's investments. We use a least square dummy variable model to analyze panel data before and after switching to determine the impact of switching. Based on pooled data, our evidence is consistent with the view that NASDAQ-to-NYSE switchers have significantly lower investment-cash flow sensitivity, which means that firms rely less heavily on internal financing after switching and find accessing external financing easier. Thus, firms may benefit from switching in terms of a lower cost of external capital due to such factors as increasing visibility, liquidity, and reputation.
\end{abstract}

(c) 2008 Elsevier Inc. All rights reserved.

\section{Introduction}

Each year some managers decide to change the marketplace for trading their firms' securities. Although their motives for switching differ, a common reason is management's desire to improve a firm's visibility. Baker and Edelman (1992a,b) and Baker et al. (1999b) find a positive relation between listing switches and visibility. Improved visibility suggests greater flow and accessibility of information about a firm, which in turn may reduce information asymmetry and the uncertainty about a firm's prospects. Barry and Brown (1986) note that reducing information asymmetry and risk may enable firms to lower their cost of external capital and to reduce their financing constraints. Accordingly, when firms can easily acquire less expensive external capital by switching to a larger exchange, their investment sensitivity to cash flow should decrease.

An alternative view is that the investment-cash flow sensitivity of switching firms should increase. Dharan and Ikenberry (1995) find that firms moving the trading location of their stock to the American Stock Exchange (AMEX) or New York Stock Exchange (NYSE) generally experience poor stock returns after switching. The negative impact of switching may indicate a higher cost of external equity and greater investment-cash flow sensitivity. In addition, this poor post-listing performance may relate to managers timing the application for listing. Due to the stringent requirements for listing on the AMEX or NYSE,

\footnotetext{
* Corresponding author.

E-mail addresses: yang@management.ntu.edu.tw (C.-C. Yang),

kbaker@american.edu (H.K. Baker), lcchou@mail.ntcb.edu.tw (L.-C. Chou).

${ }^{1}$ Tel.: +1 202885 1949; fax: +1 2028851946 .
}

managers of small firms may choose to apply for listing before a decline in performance.

In this study, we use a cash flow model to examine whether a significant relation exists between listing switches and investment-cash flow sensitivity for switching firms. Given the differing views on how switching may affect investment-cash flow sensitivity, we do not predict the direction of the impact. We focus our examination on a sample of firms moving from NASDAQ to the NYSE during the period 1992-2002.

We use a least square dummy variable model to analyze panel data before and after switching to determine the impact of switching. Based on the pooled data, investment sensitivity to investment opportunities does not appear to differ between before and after switching. Our results show, however, that NASDAQ-to-NYSE switchers experience significantly lower investment-cash flow sensitivity. An implication of this finding is that switching firms benefit from a lower cost of external capital, which may be due to such factors as improved visibility, liquidity, and reputation.

Our study contributes to the literature by examining the theoretical and empirical aspects of switching trading locations. There is a large body of evidence on the issue of investment-cash flow sensitivity. Similarly, several studies explore the microstructure issues associated with switching from one equity market to another. To our knowledge, no previous study addresses how these two areas may be related. Our exploratory study seeks to fill this gap. Our evidence should be of interest to researchers studying market microstructure and to managers contemplating switching the trading location of their firm's securities.

The remainder of our paper has the following organization. In Section 2, we provide an overview of the literature on listing changes and investment-cash flow sensitivity. We describe our cash flow 
model in Section 3. In Section 4, we discuss our data and provide descriptive statistics about the marketplaces and switching companies. We present our empirical results in Section 5. In Section 6, we summarize our findings and conclude the paper by suggesting directions for further work.

\section{Related literature}

\subsection{Listing changes}

Managers face the decision of whether to switch marketplaces for trading their firms' securities. For the most part, managers of NASDAQ or AMEX firms may consider switching their listing to the NYSE. Researchers have studied the reasons for listing switches and how switches affect visibility, liquidity, and stock returns. The decision to switch often involves a complex trade-off between costs and benefits.

Some firms move from a smaller market to a larger one to achieve visibility gains. For example, news on a listing may attract attention to the company in the investment community. Merton (1987) contends that the publicity associated with listing reaches some investors who were previously unaware of the security. In addition, Barry and Brown (1986) note that listing may temporarily increase information availability due to enhanced interest, which, in turn, may reduce the uncertainty about a firm's prospects and raise the stock's price.

Baker et al. (1999a) use several proxies to test whether changes in listing from the OTC to the NYSE affect a firm's visibility. They find that increased visibility in a firm is primarily due to changes in market capitalization not due to the listing itself. Baker et al. (1999b) use similar methodology to examine a sample of firms switching from the AMEX to the NYSE. They find a positive and significant relation between switching and visibility gains.

Baker et al. (2002) show that firms listing their stocks on the NYSE or the London Stock Exchange (LSE) have significant increases in visibility in the form of increased analyst coverage and media attention. Analyst coverage and media attention are their proxies for visibility. Analyst coverage after listing is related to a decrease in the cost of equity capital in a way similar to Merton's (1987) investor recognition hypothesis. This effect is stronger for NYSE than LSE firms, which may compensate for the higher costs associated with NYSE listing.

Several studies examine the relation between listing switches and liquidity. For example, Baker and Edelman (1992a) find evidence that moving from NASDAQ to NASDAQ NMS (National Market System) tightens spreads and increases volume, which leads to enhancing a firm's liquidity by lowering transaction costs. Baker and Edelman (1992b) indicate that low versus high transaction volume AMEX stocks have more to gain in terms of visibility and market interest by switching to the NYSE. The temporary increase in attention by institutional investors may increase information flows and may reduce uncertainties about stock performance and risk. Liquidity may increase due to investor interest in the stock.

Other studies examine the market reaction to listing. For example, Grammatikos and Papaioannou (1986) and Edelman and Baker (1990) report that firms with low prelisting liquidity experience the most favorable market response to initial listing. Baker and Edelman (1992b) find that cumulative abnormal returns (CARs) rise during the prelisting period for the AMEX firms switching to the NYSE but begin to decline shortly after the approval date for the full sample. These price effects may be associated with the benefits of switching. Another explanation is that firms may be taking other actions that generate good news before listing and bad news after listing. After splitting the full sample into low-volume and high-volume subsamples, Baker and Edelman (1992b) find that the market reacts more favorably for the low-volume group. This favorable reaction may reflect not only greater visibility and market interest but also temporary increases in both information flows and expectation of liquidity gains as well as reductions in systematic risk.

\subsection{Investment-cash flow sensitivity}

Investment-cash flow sensitivity is a proxy for the degree of uncertainty of using internal funds to finance a firm's investments. In an imperfect market with information asymmetry, the cost of external capital exceeds that of internal funds. Without enough internal funds, a firm may have to resort to higher-cost external funds, which may lead to rejecting otherwise profitable investments. Hence, firms with favorable investment opportunities may want to rely on more internal sources of funds or try to reduce their cost of external funds.

The literature documenting the sensitivity of firms' investment to fluctuations in their internal funds is substantial and has grown in recent years. Hubbard (1998) provides an extensive literature review and studies by Almeida and Campello (2007) as well as Dasgupta and Sengupta (2007) present recent extensions on the topic. Beginning with Fazzari et al. (1988), these studies examine firms based on a priori measures of financing constraints such as dividend payout, size, age, or debt ratings and compare the investment-cash flow sensitivity. For example, Fazzari et al. analyze differences in investment behavior by firms classified according to earnings retention. They find that investment of firms exhausting all of their internal financing is much more sensitive to fluctuations in cash flow than that of mature, highdividend firms. They attribute these results to a financing hierarchy in which internal funds have a cost advantage over new equity and debt. Subsequent studies by Hoshi et al. (1991), Oliner and Rudenbusch (1992), Whited (1992), Schaller (1993), Gilchrist and Himmelberg (1995) and others provide support for Fazzari et al.

Early evidence suggests that investment decisions of more financially-constrained firms are more sensitive to firm liquidity than those of less constrained firms. Other researchers have challenged the generality of this conclusion. For example, Kaplan and Zingales (1997) show that investment outlays of the least constrained firms are the most sensitive to internal cash flow. Others obtain results consistent with those of Kaplan and Zinglaes including Cleary (1999), Kadapakkam et al. (1998), and Kaplan and Zingales (2002).

Allayannis and Mozumdar (2004) examine the notion that when firms incur cash losses, investment cannot respond to cash flow. They find that while negative cash flow observations explain Cleary's (1999) results, the Kaplan and Zingales (1997) results are driven more by a few influential observations in a small sample. Allayannis and Mozumdar also find a decline in investment-cash flow sensitivity over 1977-1996, especially for the most constrained firms.

Moyen (2004) shows that the conflicting regression results obtained by Fazzari et al. (1988) and Kaplan and Zingales (1997) depend on the criterion used to identify whether a firm experiences financing constraints. She constructs an unconstrained model, in which firms have perfect access to external financial markets, and a constrained model, in which firms have no access. Using low dividends to identify firms with financing constrains leads to Fazzari et al.'s results that low-dividend firm's investment is more sensitive to cash flow than high-dividend firms' investment. Using the constrained model to identify firms with financing constraints supports the results of Kaplan and Zingales that constrained firms' investment is less sensitive to cash flow than unconstrained firms' investment. Thus, the results show that cash flow sensitivity of firms described by the constrained model is lower than that described by the unconstrained model.

Froot et al. (1993) develop a model for analyzing corporate risk management policies in which external funds are more costly than internal funds. Hedging helps ensure that firms have sufficient internal funds for investment spending. Following their model, Allayannis and Mozumdar (2000) and Deshmukh and Vogt (2005) examine the difference in investment-cash flow sensitivity between hedgers and non-hedgers. The differences between these two studies lie in the sample used and the target of hedging. Allayannis and Mozumdar use a sample of firms based on the S\&P 500, while 
Deshmukh and Vogt use a sample of manufacturing firms. The former focuses on currency hedging, while the latter examines both currency and interest rate hedging. Deshmukh and Vogt find that investment spending is less sensitive to cash flow for hedgers than for nonhedgers. They also find that investment spending is less sensitive to cash flow among hedgers when the extent of hedging is higher. The results of both studies are consistent with the implications of the model by Froot et al.

\section{Cash flow models}

Given the conflicting views on the direction and significance of the relation between listing switches and the investment-cash flow sensitivity of switching firms, the impact of listing switches on investment-cash flow sensitivity remains an empirical issue. Following Fazzari et al. (1988) and Deshmukh and Vogt (2005) among others, we use a cash flow model to examine this relation. Their original cash flow model follows:

$\frac{I_{i, t}}{K_{i, t-1}}=\beta_{0}+\beta_{1} Q_{i, t-1}+\beta_{2}\left(\frac{C F}{K}\right)_{i, t-1}+\varepsilon_{i, t}$

where $I$ is capital expenditures in the cash flow statement; $K$ is the net fixed assets in the balance sheet; $Q$ is Tobin's $Q$, which is the market value of total assets over the book value of total assets, and the market value of total assets is equal to market value of total equity plus the book value of total debt; $\mathrm{CF}$ is the cash flow from operating activities in the cash flow statement; $\varepsilon$ is the error term; and $i$ and $t$ are the specific firm and period, respectively.

In this original cash flow model, $\beta_{1}$ measures how firms' investment decisions react to their investment opportunities $(Q)$. If $\beta_{1}$ is positive (negative), firms increase (decrease) their investments when they expect better investment opportunities. $\beta_{2}$ measures firms' investment sensitivity to their cash flows.

Our cash flow model uses the slope dummy approach to examine the difference of the regression coefficients between the before- and after-switching regression:

$\frac{I_{i, t}}{K_{i, t-1}}=\beta_{0}+\beta_{1} Q_{\mathrm{i}, t-1}+\beta_{2} D Q_{\mathrm{i}, t-1}+\beta_{3}\left(\frac{\mathrm{CF}_{i, t}}{K_{i, t-1}}\right)+\beta_{4} D\left(\frac{\mathrm{CF}_{i, t}}{K_{i, t-1}}\right)+\varepsilon_{i, t}$

where $I, K, Q, C F$, and $\varepsilon$ are as defined before and $D$ is the slope dummy variable ( $D=0$ and $D=1$ denote the observations for NASDAQ firms before and after switching to the NYSE, respectively).

In our model, the slope dummy variable is 0 and 1 for the sample of observations before and after switching, respectively. $\beta_{1}$ and $\beta_{3}$ measure the regression coefficients of investment on the $Q$ and $\mathrm{CF}$ variables, respectively, for the sample before switching. $\beta_{2}$ and $\beta_{4}$ measure the difference in regression coefficients of investment on the $Q$ and $C F$ variables between the sample before and after switching. If $\beta_{1}$ is positive (negative), it indicates that positive (negative) investment- $Q$ sensitivity exists before switching. We expect the sign of $\beta_{1}$ to be positive, since firms tend to increase their investments when they expect good opportunities ( $Q$ ). If $\beta_{3}$ is positive (negative), it indicates that a positive (negative) investment-cash flow sensitivity exists before switching. Empirically, the sign of $\beta_{3}$ is ambiguous. Less (greater) investment sensitivity of cash flow indicates a lower (higher) cost of external funds, as indicated by Allayannis and Mozumdar (2000) and Deshmukh and Vogt (2005).

The signs of $\beta_{2}$ and $\beta_{4}$ are also an empirical issue. To our knowledge, no previous literature exists about whether firms have a greater investment- $Q$ or investment-cash flow sensitivity after switching. We conduct panel regressions for each year and pooled years, using four years of data $\left(t_{-4}, t_{-3}, t_{-2}, t_{-1}\right.$ and $\left.t_{+1}, t_{+2}, t_{+3}, t_{+4}\right)$. For comparison purposes, we also use two $\left(t_{-2}, t_{-1}\right.$ and $\left.t_{+1}, t_{+2}\right)$ and three years of data $\left(t_{-3}, t_{-2}, t_{-1}\right.$ and $\left.t_{+1}, t_{+2}, t_{+3}\right)$.

\section{Data and methodology}

\subsection{Overview of NASDAQ and the NYSE}

In addition to dissimilarities in visibility, liquidity, and reputation, NASDAQ and the NYSE differ in other respects such as size, market microstructure, and risk-return characteristics. NASDAQ is the largest U.S. electronic stock market with about 3200 companies and, on average, trades more shares per day than any other U.S. market. The NYSE is the largest stock exchange in the world by dollar volume and, with about 2800 listed companies, has the second most securities of all stock exchanges. As of December 31, 2007, the combined capitalization of all NYSE-listed companies was about \$27.1 trillion, which is much greater than NASDAQ. Another distinguishing characteristic is that NASDAQ is a dealer market, while the NYSE is primarily an auction market. Compared to the NASDAQ composite index, the NYSE composite index has a lower daily mean return and volatility as measured by the standard deviation of daily mean returns.

\subsection{Data sources and sample}

We identify NASDAQ-to-NYSE switches between 1992 and 2005 using the NYSE Factbook and use COMPUSTAT to obtain financial data between 1988 and 2006. Table 1 indicates the number of NASDAQ-toNYSE switches during the period 1992-2005. Of the 573 listing switches, we exclude 149 firms not in the database (missing firms), 105 financial firms (banking, insurance and security firms), and 15 firms with missing data on variables used for testing. Thus, we obtain an initial sample of 304 firms between 1992 and 2005. Financial data on missing firms are unavailable due largely to mergers and acquisitions. We drop financial firms from our sample because they differ substantially from industrial firms in terms of fixed asset investments and financing. Our sample excludes IPOs, and bankruptcies play a minor role involving the missing data. Our testing sample of 304 consists of 200 firms with December year ends and 104 firms with non-December fiscal year ends.

The number of switches trends upward between 1992 and 1997, which coincides with a period of economic growth in which some firms could more easily meet NYSE listing requirements. The number of listing switches decreases in 1998 and 1999, a super-bullish period in which NASDAQ firms generally experienced outstanding stock price performance and had ready access to financing. Not surprisingly, fewer NASDAQ firms transferred to the NYSE during this period of a stock market bubble. The relatively low number of switches during

Table 1

Companies switching from NASDAQ to the NYSE between 1992 and 2005

\begin{tabular}{|c|c|c|c|c|c|}
\hline Year & $\begin{array}{l}\text { Number } \\
\text { switching }\end{array}$ & $\begin{array}{l}\text { Firms not in } \\
\text { the database }\end{array}$ & $\begin{array}{l}\text { Financial } \\
\text { firms }\end{array}$ & $\begin{array}{l}\text { Firms with } \\
\text { missing data }\end{array}$ & $\begin{array}{l}\text { Testing } \\
\text { sample size }\end{array}$ \\
\hline 1992 & 45 & 19 & 7 & 1 & 18 \\
\hline 1993 & 45 & 13 & 11 & 1 & 20 \\
\hline 1994 & 41 & 19 & 5 & 0 & 17 \\
\hline 1995 & 61 & 19 & 12 & 1 & 29 \\
\hline 1996 & 84 & 26 & 20 & 3 & 35 \\
\hline 1997 & 92 & 28 & 10 & 4 & 50 \\
\hline 1998 & 66 & 12 & 12 & 2 & 40 \\
\hline 1999 & 18 & 5 & 5 & 0 & 8 \\
\hline 2000 & 24 & 5 & 1 & 0 & 18 \\
\hline 2001 & 27 & 1 & 7 & 1 & 18 \\
\hline 2002 & 36 & 1 & 8 & 1 & 26 \\
\hline 2003 & 20 & 1 & 4 & 1 & 14 \\
\hline 2004 & 9 & 0 & 3 & 0 & 6 \\
\hline 2005 & 5 & 0 & 0 & 0 & 5 \\
\hline Total & 573 & 149 & 105 & 15 & 304 \\
\hline
\end{tabular}

This table reports the distribution of firms switching from NASDAQ to the NYSE between 1992 and 2005. The test sample excludes firms not in the database, financial firms, and firms with missing data. The data source is the NYSE Factbook 2007 and COMPUSTAT North America. 
2000 and 2001 coincides with the economic downturn. During such a period, NASDAQ firms were less motivated to switch to the NYSE and were less likely to meet NYSE listing requirements. In recent years, both NASDAQ and NYSE have engaged in actively promoting the benefits of their respective markets. These factors may partially explain the decline in listing switches between 2002 and 2005.

Table 2 provides summary statistics of our sample companies before and after switching. We calculate averages for the investmentto-capital ratio, cash flow-to-capital ratio, and Tobin's $Q$ ratio for the pooled years in Panel A. We use capital to stand for net fixed assets in the balance sheet and define the ratios calculated here in Section 3. Panel B presents the results of a paired $t$-test and a Wilcoxon matched-pairs signed-rank test for pooled to investigate whether these three ratios differ significantly before and after switching data for 1992-2002 using four years of data $\left(t_{-4}, t_{-3}, t_{-2}, t_{-1}\right.$ and $t_{+1}, t_{+2}$, $\left.t_{+3}, t_{+4}\right), 1992-2003$ using three years of data $\left(t_{-3}, t_{-2}, t_{-1}\right.$ and $t_{+1}, t_{+2}$, $\left.t_{+3}\right)$, and 1992-2004 using two years of data $\left(t_{-2}, t_{-1}\right.$, and $\left.t_{+1}, t_{+2}\right)$.

As Panel A of Table 2 shows, the average investment-to-capital ratio using pooled data decreases from for each period examined. For the period 1992-2002 using four years of data before and after switching, the average investment-to-capital ratio decreases from 0.433 to 0.331 . This decrease suggests a reduction in investment risk, which could result in lower financial constraints. As Panel B of Table 2 indicates, both the paired $t$-test and the Wilcoxon test are statistically significant at the 0.01 level. Panels $C$ and D show similar results using both three years and two years of data before and after switching, respectively.

Panel A of Table 2 also shows that the average cash flow-to-capital ratio decreases from 0.786 to 0.763 over the period 1992-2002 using four years of pre- and post-switching data. This result suggests that firms have less internal funds and fewer investment opportunities

Table 2

Summary statistics and tests of companies switching from NASDAQ to the NYSE partitioned by before-switching $(D=0)$ and after-switching $(D=1)$

Panel A. Pooled data

\begin{tabular}{|c|c|c|c|c|c|c|}
\hline \multirow{2}{*}{$\begin{array}{l}\text { Switching years } \\
\text { Dummy }\end{array}$} & \multicolumn{2}{|c|}{$1992-2002$} & \multicolumn{2}{|c|}{ 1992-2003 } & \multicolumn{2}{|c|}{$1992-2004$} \\
\hline & $D=0$ & $D=1$ & $D=0$ & $D=1$ & $D=1$ & $D=1$ \\
\hline \multirow{2}{*}{$\begin{array}{l}\text { Number of firm years } \\
\text { Average investment- } \\
\text { to-capital ratio }\end{array}$} & 1116 & 1116 & 879 & 879 & 598 & 598 \\
\hline & 0.433 & 0.331 & 0.534 & 0.334 & 0.476 & 0.361 \\
\hline $\begin{array}{l}\text { Average cash flow- } \\
\text { to-capital ratio }\end{array}$ & 0.786 & 0.763 & 0.689 & 0.760 & 0.763 & 0.606 \\
\hline Average $Q$ ratio & 2.478 & 1.945 & 2.268 & 1.966 & 2.191 & 2.008 \\
\hline \multicolumn{7}{|c|}{ Panel B. Tests using pooled data } \\
\hline $\begin{array}{l}\text { Tests using } \\
\text { pooled data }\end{array}$ & \multicolumn{2}{|c|}{$\begin{array}{l}\text { Average investment- } \\
\text { to-capital ratio }\end{array}$} & \multicolumn{2}{|c|}{$\begin{array}{l}\text { Average cash flow- } \\
\text { to-capital ratio }\end{array}$} & \multicolumn{2}{|c|}{$\begin{array}{l}\text { Average } \\
Q \text { ratio }\end{array}$} \\
\hline \multicolumn{7}{|c|}{ Panel B. 1992-2002 four years before and after switching $\left(t_{-4}, t_{-3}, t_{-2}, t_{-1}\right.$ and $\left.t_{+1}, t_{+2}, t_{+3}, t_{+4}\right)$} \\
\hline $\begin{array}{l}\text { Paired } t \text {-test } \\
\text { ( } t \text {-value) }\end{array}$ & \multicolumn{2}{|c|}{$4.248^{* *}$} & \multicolumn{2}{|c|}{$3.602^{* *}$} & \multicolumn{2}{|c|}{0.248} \\
\hline $\begin{array}{l}\text { Wilcoxon test } \\
\text { (z-value) }\end{array}$ & \multicolumn{2}{|l|}{$9.761^{* *}$} & \multicolumn{2}{|c|}{$3.440^{* *}$} & \multicolumn{2}{|c|}{0.416} \\
\hline \multicolumn{7}{|c|}{ Panel C. 1992-2003 three years before and after switching $\left(t_{-3}, t_{-2}, t_{-1}\right.$ and $\left.t_{+1}, t_{+2}, t_{+3}\right)$} \\
\hline $\begin{array}{l}\text { Paired } t \text {-test } \\
\text { (t-value) }\end{array}$ & \multicolumn{2}{|c|}{$2.633^{* *}$} & \multicolumn{2}{|c|}{$3.564^{* *}$} & \multicolumn{2}{|c|}{0.330} \\
\hline $\begin{array}{l}\text { Wilcoxon test } \\
\text { (z-value) }\end{array}$ & \multicolumn{2}{|l|}{$7.635^{* *}$} & \multicolumn{2}{|c|}{$1.995^{*}$} & \multicolumn{2}{|c|}{0.620} \\
\hline \multicolumn{7}{|c|}{ Panel D. 1992-2004 two years before and after switching $\left(t_{-2}, t_{-1}\right.$ and $\left.t_{+1}, t_{+2}\right)$} \\
\hline $\begin{array}{l}\text { Paired } t \text {-test } \\
\text { (t-value) }\end{array}$ & \multicolumn{2}{|c|}{$2.890^{* *}$} & \multicolumn{2}{|c|}{$2.042^{*}$} & \multicolumn{2}{|c|}{0.587} \\
\hline $\begin{array}{l}\text { Wilcoxon test } \\
\text { (z-value) }\end{array}$ & \multicolumn{2}{|l|}{$4.778^{* *}$} & \multicolumn{2}{|l|}{0.144} & \multicolumn{2}{|c|}{0.787} \\
\hline
\end{tabular}

*, ** Significant at the 0.05 and 0.01 levels, respectively.

This table reports summary statistics of the sample companies before and after switching. Panel A provides the average investment-to-capital ratio, average cash flow-to-capital ratio, and average $Q$ ratio for the pooled years. Panel B presents the $t$-values for the paired $t$-test and the $z$-values for the Wilcoxon matched-pairs signed-rank test for pooled data to test whether the average investment-to-capital ratio, average cash flow-to-capital ratio, and average $Q$ ratio differ significantly between before-switching $(D=0)$ and after-switching $(D=1)$. after switching. That is, these firms do not appear to achieve gains by switching to a larger exchange because the average cash flow-tocapital ratio decreases. Having less internal funds may increase financial constraints because of reduced solvency. Panel B of Table 2 presents the results of the paired $t$ and Wilcoxon tests, both of which are statistically significant at the 0.01 level. As Panels C and D show, the statistical results generally become weaker when using three and two year data before and after switching.

Panel A of Table 2 indicates that the average $Q$ ratio decreases after switching. For example, using four year data for 1992-2002, the average $Q$ ratio decreases from 2.478 before switching to 1.945 after switching. The lower average $Q$ ratio after switching may reflect reduced stock performance, which, in turn, may lead to higher financial constraints. As Panels B, C, and D show, none of the paired $t$ tests or Wilcoxon tests are statistically significant at normal levels for the average $Q$ ratio.

For testing purposes, we use panel regressions with two to four years of data before and after listing. We focus on the results using four years of data before and after switching because the investmentcash flow sensitivity estimates are likely to be more reliable using longer samples with more observations. To estimate our model for 1992-2002 using four years of data $\left(t_{-4}, t_{-3}, t_{-2}, t_{-1}\right.$ and $t_{+1}, t_{+2}, t_{+3}$, $\left.t_{+4}\right)$, we use 279 companies and 2232 observations $(8 \times 279)$. For example, for NASDAQ-to-NYSE switchers in 2002, we include data between 1998-2001 (before listing) and 2003-2006 (after listing). Estimating our cash flow model for 1992-2003 using three years of data $\left(t_{-3}, t_{-2}, t_{-1}\right.$ and $\left.t_{+1}, t_{+2}, t_{+3}\right)$ involves 293 companies and 1758 observations $(6 \times 293)$. When applying two years of data $\left(t_{-2}, t_{-1}\right.$, and $\left.t_{+1}, t_{+2}\right)$ to estimate our model for 1992-2004, we have 299 companies and 1196 observations $(4 \times 299)$ for our analysis.

\section{Empirical evidence}

In Table 3, we present the empirical results of the question of whether firms increase their investments when they expect better investment opportunities as well as whether switching from NASDAQ to the NYSE in years affects investment-cash flow sensitivity. Panel A contains the regression results for individual years using four-year panel regressions. Panels B, C, and D report the results of the pooled regressions using four, three, and two years of data, respectively. In interpreting the results of Table 3, we believe the pooled results and four-year panel regressions have greater reliability than the single year results because of the larger sample size.

\subsection{Investment decisions and opportunities}

In the regression model, $\beta_{1}$ measures how firms' investment decisions react to their investment opportunities $(Q)$ before switching. If $\beta_{1}$ is positive (negative), firms increase (decrease) their investments when they expect better investment opportunities. $\beta_{2}$ shows how these firms' investment decisions when facing investment opportunities may differ before and after switching. If the coefficient $\left(\beta_{2}\right)$ of the investment dummy $D Q$ is positive (negative), firms have more (less) investment sensitivity to investment opportunities after switching than before switching.

As Panel A of Table 3 shows, $\beta_{1}$ for $Q$ is positive in 10 of the 11 years and significantly positive in 6 of the 11 years $(1992,1996,1997,2000$, 2001 , and 2002). $\beta_{1}$ for $Q$ is significantly negative in 1994 . Since $\beta_{1}$ is generally positive, this suggests that firms typically increase their investments when they expect better investment opportunities. Panel $B$ indicates that $\beta_{1}$ for the four-year pooled data is positive and significant at the 0.01 level. As Panels $C$ and D show, similar results occur when using three-year and two-year pooled data in that $\beta_{1}$ for $Q$ is positive and statistically significant at normal levels. These results support our expectation and provide evidence that firms tend to increase their investments when they expect better investment opportunities before switching. 
Table 3

Tests on whether switching from NASDAQ to the NYSE affects investment-cash flow sensitivity

\begin{tabular}{|c|c|c|c|c|c|c|c|c|c|}
\hline \multirow[t]{2}{*}{ Year } & \multirow[t]{2}{*}{ Intercept } & \multirow[t]{2}{*}{$Q$} & \multirow[t]{2}{*}{$D Q$} & \multirow[t]{2}{*}{$(\mathrm{CF} / \mathrm{K})$} & \multirow[t]{2}{*}{$D(\mathrm{CF} / K)$} & \multirow[t]{2}{*}{ Adj. $R^{2}$} & \multicolumn{3}{|c|}{ Number of observations } \\
\hline & & & & & & & Total & $D=0$ & $D=1$ \\
\hline \multicolumn{10}{|c|}{ Panel A. Individual years } \\
\hline 1992 & $0.193(2.57)^{*}$ & $0.150(3.83)^{* *}$ & $-0.042(-1.09)$ & $0.056(1.77)^{*}$ & $-0.06(-1.17)$ & 0.117 & 144 & 72 & 72 \\
\hline 1993 & $0.364(5.74)^{* *}$ & $0.012(1.03)$ & $-0.045(-0.88)$ & $0.050(1.52)$ & $-0.057(-1.04)$ & 0.011 & 160 & 80 & 80 \\
\hline 1994 & $4.77(9.68)^{* *}$ & $-3.530(-18.10)^{* *}$ & $1.381(4.50)^{* *}$ & $2.062(58.20)^{* *}$ & $-1.79(-2.45)^{*}$ & 0.961 & 136 & 68 & 68 \\
\hline 1995 & $0.768(1.89)^{*}$ & $0.004(0.03)$ & $-1.122(-0.66)$ & $0.203(3.51)^{* *}$ & $-0.237(-1.22)$ & 0.037 & 232 & 116 & 116 \\
\hline 1996 & $0.234(6.39)^{* *}$ & $0.065(6.15)^{* *}$ & $-0.023(-0.98)$ & $0.062(2.63)^{* *}$ & $-0.047(-1.48)$ & 0.184 & 280 & 140 & 140 \\
\hline 1997 & $0.278(11.30)^{* *}$ & $0.051(6.93)^{* *}$ & $-0.009(-0.778)$ & $-0.004(-0.69)$ & $0.038(2.52)^{*}$ & 0.127 & 400 & 200 & 200 \\
\hline 1998 & $0.361(10.90)^{* *}$ & $0.002(0.60)$ & $-0.022(-1.07)$ & $0.019(1.68)^{*}$ & $-0.009(-0.62)$ & 0.003 & 320 & 160 & 160 \\
\hline 1999 & $0.319(4.04)^{* *}$ & $0.052(1.20)$ & $-0.153(-2.53)^{*}$ & $-0.067(-1.24)$ & 0.267 (1.39) & 0.119 & 64 & 32 & 32 \\
\hline 2000 & $0.238(7.03)^{* *}$ & $0.025(2.36)^{*}$ & $-0.007(-0.42)$ & $0.021(2.27)^{*}$ & $-0.043(-3.32)^{* *}$ & 0.101 & 144 & 72 & 72 \\
\hline 2001 & $0.254(7.43)^{* *}$ & $0.117(7.59)^{* *}$ & $-0.080(-5.02)^{* *}$ & $-0.018(-0.98)$ & $0.029(1.45)$ & 0.283 & 144 & 72 & 72 \\
\hline 2002 & $0.260(8.93)^{* *}$ & $0.054(5.61)^{* *}$ & $-0.070(-3.48)^{* *}$ & $0.048(4.90)^{* *}$ & $0.072(2.97)^{* *}$ & 0.626 & 208 & 104 & 104 \\
\hline \multicolumn{10}{|c|}{ Panel B. 1992-2002 four years before and after switching $\left(t_{-4}, t_{-3}, t_{-2}, t_{-1}\right.$ and $\left.t_{+1}, t_{+2}, t_{+3}, t_{+4}\right)$} \\
\hline 1992-2002 pooled & $0.336(19.50)^{* *}$ & $0.015(4.35)^{* *}$ & $-0.009(-0.91)$ & $0.043(5.99)^{* *}$ & $-0.032(-2.67)^{* *}$ & 0.031 & 2232 & 1116 & 1116 \\
\hline \multicolumn{10}{|c|}{ Panel C. 1992-2003 three years before and after switching $\left(t_{-3}, t_{-2}, t_{-1}\right.$ and $\left.t_{+1}, t_{+2}, t_{+3}\right)$} \\
\hline 1992-2003 pooled & $0.335(5.64)^{* *}$ & $0.043(2.16)^{*}$ & $-0.023(-0.74)$ & $0.089(6.22)^{* *}$ & $-0.088(-4.90)^{* *}$ & 0.029 & 1758 & 879 & 879 \\
\hline \multicolumn{10}{|c|}{ Panel D. 1992-2004 two years before and after switching $\left(t_{-2}, t_{-1}\right.$ and $\left.t_{+1}, t_{+2}\right)$} \\
\hline 1992-2004 pooled & $0.268(8.12)^{* *}$ & $0.077(6.40)^{* *}$ & $-0.020(-1.22)$ & $0.021(2.39)^{*}$ & $-0.020(-1.98)^{*}$ & 0.047 & 1196 & 598 & 598 \\
\hline
\end{tabular}

*, ** Significant at the 0.05 and 0.01 levels, respectively.

The following regression model produces the results reported in this table:

$\frac{I_{i, t}}{K_{i, t-1}}=\beta_{0}+\beta_{1} Q_{i, t-1}+\beta_{2} D Q_{i, t-1}+\beta_{3}\left(\frac{\mathrm{CF}_{i, t}}{K_{i, t-1}}\right)+\beta_{4} D\left(\frac{\mathrm{CF}_{i, t}}{K_{i, t-1}}\right)+\varepsilon_{i, t}$

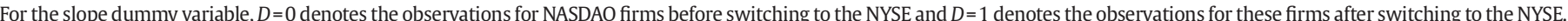

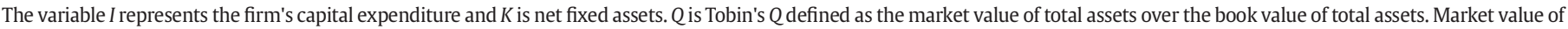

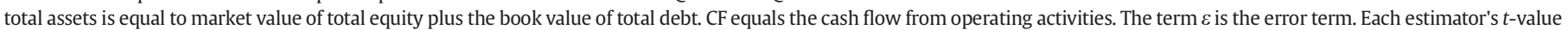
and $F$-value is in parenthesis. The regression coefficient on $D(\mathrm{CF} / K)$ can be interpreted as the difference of investment-cash flow sensitivity between $D=0$ and $D=1$.

Our evidence is generally consistent with the findings in previous studies such as Fazzari et al. (1988) and Kaplan and Zingales (1997). In their study on the effects of $Q$ on investment, Fazzari et al. find all positive regression coefficients for each of the three dividendretention classes for the period 1970-1979 and 1970-1984, and one negative and two positives for the period 1970-1975. Kaplan and Zingales also report all positive $Q$ regression coefficients for all six financially-constrained classes for the period 1970-1977 and 4 of the 6 positive $Q$ regression coefficients for the period 1978-1984.

$\beta_{2}$ shows how these firms' investment decisions, when facing investment opportunities, may differ before and after switching. For the four-year regressions, Panel A of Table 3 shows that $\beta_{2}$ is significantly negative in 3 of the 11 years (1999, 2001 and 2002) and significantly positive in one year (1994). As Panel B reveals for the pooled data, $\beta_{2}$ is negative but not statistically significant at normal levels. As Panels $C$ and D show, $\beta_{2}$ using pooled data for three and two years before and after listing, respectively, is also negative but not statistically significant. Thus, based on the pooled data, firms do not appear to have more or less investment sensitivity to investment opportunities after switching than before switching.

\subsection{Investment-cash flow sensitivity}

$\beta_{3}$ measures firms' sensitivity of investment to cash flow before switching. As $\beta_{3}$ increases, investment-cash flow sensitivity also increases. $\beta_{4}$ measures the difference in regression coefficients of investment on cash flow variables between the sample before and after switching.

Fazzari et al. (1988) indicate that high (low) dividend payout firms have low (high) sensitivity of investment to cash flow. The significance of the cash flow regression coefficient is evidence of the degree of financing constraints facing firms. Allayannis and Mozumdar (2000) and Deshmukh and Vogt (2005) use this coefficient to indicate that as firms' volatility of cash flow increases (decreases), their sensitivity of investment to cash flow will be higher (lower). Both studies indicate that hedging against interest or exchange rate risk lowers the volatility of firms' cash flows and hence reduces the firms' cost of external capital.

For the four-year regressions in Panel A of Table 3, $\beta_{3}$ is significantly positive in 7 of 11 years $(1992,1994,1995,1996,1998,2000$, and 2002), but never significantly negative during the period 1992-2002. As Panel B shows, $\beta_{3}$ for the pooled data is significantly positive at the 0.01 level. As Panels $C$ and $D$ show, the results for the pooled data using three-year and two-year regressions, respectively, are also positive and statistically significant at normal levels. A positive $\beta_{3}$ indicates that positive investment-cash flow sensitivity exists before switching.

As previously discussed, conflicting views exist on whether a firm's sensitivity of investment to cash flow is higher or lower after switching. If the coefficient $\left(\beta_{4}\right)$ of the cash flow dummy $D\left(\mathrm{CF} / K_{i, t-1}\right)$ is negative, this indicates that investment-cash flow sensitivity decreases after switching. A negative coefficient means that firms rely less heavily on internal financing after switching, which suggests they may find accessing external financing easier. We then have evidence that firms may benefit from switching in terms of a lower cost of external capital due to such factors as increasing visibility, liquidity, and reputation. However, if $\beta_{4}$ of the cash flow dummy $D(\mathrm{CF} /$ $\left.K_{i, t-1}\right)$ is positive, this indicates that investment-cash flow sensitivity increases after switching, which Dharan and Ikenberry (1995) indicate is evidence that firms may time the switching.

As shown in Panel A of Table 3, the four-year regressions for the individual years reveal mixed results involving investment-cash flow sensitivity before and after switching. That is, over the period 19922002 , the sign of $\beta_{4}$ is significantly positive in 2 of the 11 years (1997 and 2002), and statistically negative in 2 of the 11 years (1994 and 2000). Using the pooled data regression with four-year data to examine the impact of the switch, $\beta_{4}$ is significantly negative at the 0.01 level. A negative coefficient on $D\left(\mathrm{CF} / K_{i, t-1}\right)$ may indicate that firms have less investment-cash flow sensitivity due to a lower cost of external capital after switching. This result supports the view that 
positive effects exist for NASDAQ-to-NYSE switches. Panels C and D also show that $\beta_{4}$ is significantly negative at normal levels when using pooled data with three- and two-year regressions, respectively.

\section{Conclusion and directions for future work}

We investigate the relation between listing switches and investment-cash flow sensitivity by analyzing a sample of NASDAQ-to-NYSE switches mainly over the period 1992-2002. Contrary views exist on the effect of listing switches on investment sensitivity to cash flow. We conduct panel regressions to determine whether firms increase their investments when they expect better investment opportunities and whether switching from NASDAQ to the NYSE affects investment-cash flow sensitivity. We focus on using four-year data before and after switching to test the impact of switching.

Our results using pooled data show that the sensitivity to investment opportunities does not differ significantly before versus after switching. Based on pooled data over 1992-2002, our evidence is consistent with the view that NASDAQ-to-NYSE switchers experience significantly lower investment-cash flow sensitivity. This finding means that firms rely less heavily on internal financing after switching and find accessing external financing easier. Consequently, firms may benefit from switching in terms of a lower cost of external capital due to such factors as increasing visibility, liquidity, and reputation.

In this study, we have taken an initial step to examine the relation between switching and investment-cash flow sensitivity. Future avenues exist for more work on theoretical and empirical modeling related to this topic. For example, one avenue would be to investigate whether investment sensitivity to cash flow significantly changes for switches between other exchanges, such as moves from the AMEX to the NYSE, or when dual or cross-listing occurs. Another direction for further work would be to investigate whether the investment sensitivity to cash flow significantly changes when a firm delists from an exchange.

\section{References}

Allayannis G, Mozumdar A. Cash flow, investment, and hedging. Working paperUniversity of Virginia; 2000

Allayannis G, Mozumdar A. The impact of negative cash flow and influential observations on investment-cash flow sensitivity estimates. J Bank Financ 2004;28(5):901-30,

Almeida H, Campello M. Financial constraints, assets tangibility and corporate investment. Rev Financ Stud 2007;20(5):1429-60.
Baker HK, Edelman RB. The effects on spread and volume of switching to the NASDAQ National Market System. Financ Anal J 1992a;48(1):83-8.

Baker HK, Edelman RB. AMEX-to-NYSE transfers, market microstructure, and shareholder wealth. Financ Manage 1992b;21(4):60-72.

Baker HK, Powell GE, Weaver DG. Does NYSE listing affect firm visibility? Financ Manage 1999a;28(2):46-54.

Baker HK, Powell GE, Weaver DG. Listing changes and visibility gains. Q J Bus Econ 1999b;38(1):46-63.

Baker HK, Nofsinger JR, Weaver DG. International cross-listing and visibility. J Financ Quant Anal 2002;37(3):495-511.

Barry CB, Brown SJ. Limited information as a source of risk. J Portf Manage 1986;12 (2):66-73.

Cleary $\mathrm{S}$. The relationship between firm investment and financial status. J. Finance 1999;54(2):673-92.

Dasgupta S, Sengupta K. Corporate liquidity, investment and financial constraints: implications for a multi-period model. J Financ Intermed 2007;16(2):151-74.

Deshmukh S, Vogt SC. Investment, cash flow, and corporate hedging. J Corp Finance 2005;11(4):628-44.

Dharan BG, Ikenberry DL. The long-run negative drift of post-listing stock returns J Finance 1995;50(5):1547-74.

Edelman RB, Baker HK. Liquidity and stock exchange listing. Financ Rev 1990;25 (2):231-50.

Fazzari SM, Hubbard RG, Petersen BC. Financing constraints and corporate investment Brookings Pap Econ Act 1988;1:141-95.

Froot KA, Scharfstein DS, Stein JC. Risk management: coordinating corporate investment and financing policies. J Finance 1993:48(5):1629-58.

Gilchrist S, Himmelberg C. Evidence on the role of cash flow in reduced-form investment equations. J Monet Econ 1995;36(3):541-72.

Grammatikos T, Papaioannou GJ. Market reaction to NYSE listings: tests of the marketability gains hypothesis. J Financ Res 1986;9(3):215-28.

Hoshi T, Kashyap AK, Scharfstein D. Corporate structure, liquidity, and investment evidence from Japanese panel data. Q J Econ 1991;106(1):33-60.

Hubbard RG. Capital market imperfections and investment. J Econ Lit 1998;36 (1):193-225.

Kadapakkam PR, Kumar C, Riddick LA. The impact of cash flows and firm size on investment: the international evidence. J Bank Finance 1998;22(3):293-320.

Kaplan SN, Zingales L. Do investment-cash flow sensitivities provide useful measures of financing constraints? QJ Econ 1997;112(1):169-215.

Kaplan SN, Zingales L. Investment-cash flow sensitivities are not valid measures of financing constraints. Q J Econ 2002;115(2):707-12.

Merton RC. Presidential address: a simple model of capital market equilibrium with incomplete information. J Finance 1987;42(3):483-510.

Moyen N. Investment-cash flow sensitivities: constrained versus unconstrained firms. J Finance 2004;59(5):2061-92.

Oliner SD, Rudenbusch GD. Source of the financing hierarchy for business investment Rev Econ Stat 1992;74(4):643-54.

Schaller H. Asymmetric information, liquidity constraints, and Canadian investment. Can J Econ 1993;26(3):552-74

Whited T. Debt, liquidity constraints, and corporate investment: evidence from pane data. J Finance 1992;47(4):1425-60. 